\title{
VAGINAL HYSTERECTOMY COMPARED TO ABDOMINAL AND LAPAROSCOPIC HYSTERECTOMIES IN PATIENTS WITHOUT UTERINE PROLAPSE
}

\author{
Birsen Bilge, ${ }^{1}$ Ayse Zehra Ozdemir, ${ }^{1}$ Pervin Karli, ${ }^{2}$ Idris Kocak ${ }^{1}$ \\ ${ }^{1}$ Ondokuz May2s University, Department of Gynecology and Obstetrics, Turkey \\ ${ }^{2}$ Amasya University, Department of Gynecology and Obstetrics, Turkey
}

Primljen/Received 06. 09. 2018. god.

Abstract: Introduction: Except for the uterine prolapse indication, vaginal hysterectomy has been less popular than abdominal hysterectomy because the latter is considered safer and easier and surgeons often lack sufficient experience on the former. This study aims at comparing a group of patients without prolapse who underwent vaginal hysterectomy to another group of patients who underwent abdominal and laparoscopic hysterectomies with respect to intraoperative and early postoperative complications. Materials and Methods: We retrospectively reviewed the files of patients who presented to the gynecology outpatient clinic of Ondokuz May2s University (OMU), Turkey, between January 2013 and February 2018 and for whom hysterectomy was decided due to benign indications other than uterine prolapse. A total of 105 patients, 35 from each of the groups who underwent abdominal, laparoscopic and vaginal hysterectomies, were included in the study. The vaginal hysterectomy group was compared to the abdominal and laparoscopic hysterectomy patient groups with respect to duration of operation, decrease in hematocrit, blood transfusion, duration of hospitalization, hospital expenses, postoperative pain, wound site infection, and complications of intestine, bladder and ureter. Results: No statistically significant differences were found between the demographic characteristics of the groups. Vaginal hysterectomy was shown to be superior to laparoscopic and abdominal hysterectomies with respect to mean duration of operation $(p<0.005)$, decrease in hematocrit showing the amount of bleeding $(\mathrm{p}<0.005)$, duration of hospitalization ( $p<0.005)$, hospital expenses $(p<0.005)$ and amount of postoperative analgesic need $(\mathrm{p}<0.005)$. Wound site infection was found more in abdominal hysterectomy than in vaginal and laparoscopic hyster-
Prihvaćen/Accepted 17. 10. 2018. god.

ectomies $(\mathrm{p}<0.005)$. No statistically significant difference was found between vaginal, abdominal and laparoscopic hysterectomies with respect to blood transfusion and complications of intestine, bladder and ureter $(p>0.005)$. Conclusion: The most important factor in choosing a hysterectomy method is the experience of the surgeon. However, vaginal hysterectomy should be the primarily preferred method, if possible, for being more advantageous in many respects.

Key words: Hysterectomy, Minimal invasive surgery, Vaginal hysterectomy.

\section{INTRODUCTION}

Hysterectomy occupies a large portion of the routine practices of gynecologists (1). It is a major gynecological surgical operation performed most frequently after cesarean section operations (2). According to the records of the Disease Control and Prevention Center in the United States of America (USA), hysterectomy has been applied to 8.6 million women over 15 years of age between 1980 and 1993 (3). While it is estimated that hysterectomy will be administered to approximately $20 \%$ of the women aged around 55 in the United Kingdom, the rate of hysterectomy in the age interval of $40-70$ is calculated to be $15 \%$ in Italy $(4,5)$. The number of hysterectomies is approximately 20000 a year in Australia and approximately 10000 in Finland $(6,7)$. Although there is no figure available for Turkey, we think that these numbers are also applicable to our country. Hysterectomy can be performed abdominally, vaginally, laparoscopically, robotically or using a combination of various techniques as in laparoscopy-assisted vaginal hysterectomy (8). Based on the meta-analyses made by Cochrane in recent years, the American 
College of Obstetrics and Gynecology (ACOG) recommends vaginal hysterectomy to be the first choice in benign diseases $(9,10)$. Despite this, the 2003 records in the USA show that $66.1 \%$ of hysterectomies were abdominal, 21.8\% vaginal and $11.8 \%$ laparoscopic (8). Abdominal hysterectomy is more popular because a large abdominal incision is easier and surgeons are not so confident when performing a vaginal hysterectomy (11). Vaginal hysterectomy should always be the first choice as long as there is no contraindication in women who had a delivery (12). Vaginal hysterectomy is a surgical intervention that involves no visible scar tissue and thus does not raise any esthetic concern and its postoperative period is rather comfortable (13). Since there is no visible scar tissue, it is obviously superior also in terms of wound site infection. Considering that intraoperative bleeding is less in experienced hands, hospitalization and recovery times are shorter, postoperative pain is milder and the cost is lower, the technique to be primarily chosen for the patient should be vaginal hysterectomy (14).

Laparoscopic hysterectomy is also superior to abdominal surgery and these patients also return to their daily lives in a short time like the ones who are undergone vaginal hysterectomy $(15,16)$. However, compared to abdominal and vaginal hysterectomies, the duration of surgery is the longest in laparoscopic hysterectomy and intraoperative wounding, especially that of the urinary system, is more common compared to the other methods (17). Additionally, laparoscopic hysterectomy is the most expensive technique as compared to abdominal and vaginal hysterectomies (10). There are no studies showing the superiority of robotic or single-port hysterectomy to the conventional laparoscopic hysterectomy (12). There is still no consensus among surgeons as to which method is the most appropriate $(12,18)$. There are many randomized studies comparing the outcomes of hysterectomy types (18). The decision on the surgical technique to be chosen depends on the training and experience of the surgeon, the indication of the operation, the size and weight of the uterus and the number of past abdominal operations (19). In this study, 35 patients without prolapse who underwent vaginal hysterectomy in our clinic due to benign hysterectomy indication between January 2013 and February 2018 were compared to patients who underwent abdominal and laparoscopic hysterectomies with respect to intraoperative and postoperative complications.

\section{MATERIAL AND METHODS}

The outcomes of the patients without prolapse who presented to the gynecology outpatient clinic of the Gynecology and Obstetrics Clinic of Ondokuz Mayıs University (OMU) and underwent hysterectomy due to benign indication were compared with respect to hysterectomy types (vaginal, abdominal and laparoscopic) in this study. The objective of the study was to compare the preoperative, intraoperative and postoperative outcomes of these three groups of operated patients in terms of duration of operation, decrease in hematocrit, duration of hospitalization, hospital expenses, need for postoperative analgesia, complications of bladder and ureter, wound site infection, complications of intestine and blood transfusion. The files of the patients who underwent hysterectomy between January 2013 and February 2018 were reviewed retrospectively. There were a total of 2442 hysterectomy cases between these dates and 1789 of these were found to undergo abdominal, 227 vaginal and 426 laparoscopic hysterectomies. In the study, 35 patients without prolapse who underwent vaginal hysterectomy were compared to two separate groups of 35 patients each who had the same characteristics and underwent abdominal and laparoscopic hysterectomies. The indications of hysterectomy consisted of benign gynecological reasons in the study. Those who had genital system malignity were excluded from the study. Indications associated with pelvic relaxation such as genital prolapse and cystocele were also left out. The study included patients with indications of cervical intraepithelial neoplasia, endometrial hyperplasia/polyp, adnexal mass, myoma uteri, adenomyosis, dysfunctional uterine bleeding (DUB), and postmenopausal bleeding. Demographic parameters including age, BMI, gravida, parity, past abdominal surgery and American Society of Anesthesiologists (ASA) scores were compared. The cases were managed by an experienced surgeon and two assistant surgeons. All patients were given the same premedication and operated under general anesthesia. The intestinal cleanse of all patients was performed using Sodium Dihydrogen Phosphate + Disodium Hydrogen Phosphate. During their operations, all patients were administered intravenous (IV) 2 gm cefazolin sodium in 1000 milligram $(\mathrm{mg})$ ampoules. The prophylactic anti-biotherapy was continued with $2 \times 1 \mathrm{gm}$ of IV cefazolin sodium at postoperative day 1 . All laparoscopic procedures were carried out using video monitoring equipment in modified lithotomy position. A laparoscope with $10-\mathrm{mm}$ panoramic view (StorzGmBH, Germany) was connected to the standard sub-umbilical region. Subsequently, trocars with 5-mm flap-valves were placed. All instruments used during the laparoscopic procedures were reusable. All vaginal hysterectomies were completed using Liga Sure dolphin $5 \mathrm{~mm}$ 37 centimeter $(\mathrm{cm})$ LS1500 (COVIDIEN, USA) in lithotomy position. All abdominal hysterectomies were 
performed with standard type-1 hysterectomy technique and a Foley catheter was used for bladder drainage for postoperative 24 hours. A gauze stype was vaginally placed after the operation in patients who underwent vaginal hysterectomy and it was removed 24 hours later. In all operations, the time lapsed from the first surgical incision to the completion of all surgical procedures and closure of the incision site was calculated as the "duration of operation". All pieces sent to the pathology were weighed and noted. The analgesia applied when necessary in the postoperative period was given according to a certain schedule. This schedule involved $50 \mathrm{mg}$ of intravenous (IV) Dolantin in 4-hour intervals within the first postoperative 12 hours, then $75 \mathrm{mg}$ of intramuscular (IM) or IV diclofenac sodium or $100 \mathrm{mg}$ of diclofenac sodium in the form of oral tablets. The total analgesic dose given to the patients and the time in which they were in need of analgesics were calculated. The hematocrit value of each patient was measured at preoperative and postoperative day 2 to calculate the blood lost during the operation. The duration of hospitalization was taken as the number of days from the day of operation to the day of discharge. The cost analysis for each patient was based on the data obtained from the OMU system records. Since preoperative preparation was the same for every patient, it was excluded from the comparative cost analysis. The three groups of patients who had abdominal, vaginal and laparoscopic hysterectomies were compared with respect to injuries of major organs such as intestines, bladder and ureters, decrease in hematocrit, blood transfusion, duration of operation, duration of hospitalization, hospital expenses, postoperative pain, and wound site infection. This study was conducted after having been found ethically appropriate by the decision of Samsun OMU Clinic Trials Ethics Committee numbered 111 and dated 15 March 2018. The data obtained were analyzed on the SPSS (Statistics Program for Social Sciences) version 20.0 and R programs. The One Way Analysis of Variance (ANOVA) [Kruskal Wallis] was used to identify the differences within the groups being studied, and the Chi-Square Test, Fisher Exact
Test and frequency analyses to show the relationships and differences between the variables. Values of $p<$ 0.05 were considered to be significant.

\section{RESULTS}

From the patients who presented to our hospital between January 2013 and February 2018, a total of 105 patients with similar demographic characteristics, 35 from each of the groups who underwent vaginal, abdominal and laparoscopic hysterectomies due to benign indications other than prolapse, were included in the study. The mean age of the patients who underwent vaginal hysterectomy was 50.91, their mean body mass index (BMI) 30.3, mean gravida 4.42, mean parity 3.48 and mean ASA score 1.65; the mean age of the patients who underwent abdominal hysterectomy was 51.05, their mean BMI 30.89, mean gravida 4.11, mean parity 3.42 and mean ASA score 1.51; the mean age of the patients who underwent laparoscopic hysterectomy was 50.08, their mean BMI 30.02, mean gravida 3.71, mean parity 2.62 and mean ASA score 1.60. The number of past abdominal operations was calculated to be $12(30 \%)$ for vaginal hysterectomy, $13(32.5 \%)$ for abdominal hysterectomy and 15 (37.5\%) for laparoscopic hysterectomy. The age factor was observed not to have any significant effect on the surgical methods used $(p>0.05)$. There was no significant correlation between the surgical methods used and BMI $(p>0.05)$ nor there was any significant correlation between the other variables (gravida, parity and ASA score) and the surgical methods $(p>0.05)$. The number of patients who had undergone a past abdominal operation and underwent vaginal hysterectomy was $12(30 \%)$, the number of those who underwent abdominal hysterectomy was $13(32.5 \%)$ and the number of those who underwent laparoscopic hysterectomy was 15 (37.5\%) and there was no correlation between this parameter and the surgical methods $(\mathrm{p}>0.05)$. The demographic characteristics of the patients by their hysterectomy types are summarized in Table 1. The indications for all these three groups were cervical intraepithelial neoplasia,

Table 1. Demographic characteristics of patients with respect to the hysterectomy types

\begin{tabular}{|l|c|c|c|c|}
\hline \multicolumn{1}{|c|}{ Factor } & $\begin{array}{c}\text { Vaginal } \\
\text { Hysterectomy }\end{array}$ & $\begin{array}{c}\text { Abdominal } \\
\text { Hysterectomy }\end{array}$ & $\begin{array}{c}\text { Laparoscopic } \\
\text { Hysterectomy }\end{array}$ & P value \\
\hline Age & $50.91(37-72)$ & $51.05(38-69)$ & $50.08(35-70)$ & .869 \\
\hline BMI & $30.38(20-47)$ & $30.89(23-49)$ & $30.02(19-44)$ & .826 \\
\hline Gravida & $4.42(2-12)$ & $4.11(1-12)$ & $3.71(0-16)$ & .099 \\
\hline Parity & $3.48(2-8)$ & $3.42(1-10)$ & $2.62(0-10)$ & .062 \\
\hline ASA score & $1.65(1-3)$ & $1.51(1-3)$ & $1.60(1-3)$ & .515 \\
\hline Past Abdominal Operation & $12(30 \%)$ & $13(32.5 \%)$ & $15(37.5 \%)$ & .821 \\
\hline
\end{tabular}


endometrial hyperplasia/polyp, adnexal mass, myoma uteri, adenomyosis, dysfunctional uterine bleeding(DUB), and postmenopausal bleeding. No significant correlation was seen between surgical indications and surgical types $(p>0.005)$. In the patient group who were operated using the vaginal hysterectomy method, the number of patients with the indication of cervical intraepithelial neoplasia was $3(8.6 \%)$, with the indication of endometrial hyperplasia/endometrial polyp was $9(25.7 \%)$, with the indication of adnexal mass was 1 $(2.9 \%)$, with the indication of myoma uteri was 4 $(11.4 \%)$, with the indication of adenomyosis was 4 $(11.4 \%)$, with the indication of DUB was $6(17.1 \%)$ and with the indication of postmenopausal bleeding was $8(22.9 \%)$. In the patient group who were operated using the abdominal hysterectomy method, the number of patients with the indication of cervical intraepithelial neoplasia was $3(8.6 \%)$, with the indication of endometrial hyperplasia/endometrial polyp was 10 (28.6\%), with the indication of adnexal mass was 1 $(2.9 \%)$, with the indication of myoma uteri was 3 $(8.6 \%)$, with the indication of adenomyosis was 5 $(14.3 \%)$, with the indication of DUB was $5(14.3 \%)$ and with the indication of postmenopausal bleeding was $8(22.9 \%)$. Finally, in the patient group who were operated using laparoscopic hysterectomy, the number of patients with the indication of cervical intraepithelial neoplasia was $4(11.4 \%)$, with the indication of endometrial hyperplasia/endometrial polyp was 9 $(25.7 \%)$, with the indication of adnexial mass was 1 $(2.9 \%)$, with the indication of myoma uteri was 4 $(11.4 \%)$, with the indication of adenomyosis was 3 $(8.6 \%)$, with the indication of DUB was $7(20 \%)$ and with the indication of postmenopausal bleeding was 7 $(20 \%)$ (Table 2). The duration of operation was calculated as the time lapsed from the first surgical incision to the closure of the incision site. The mean duration of operation was $37.54 \mathrm{~min}$. for vaginal hysterectomy, $46.43 \mathrm{~min}$. for abdominal hysterectomy and 156.63 min. for laparoscopic hysterectomy. There were significant differences between duration of operation and the three different types of operations $(\mathrm{p}<0.005)$. The estimated amount of blood loss was calculated using the mean drop in hematocrit by measuring the patients' amount of hematocrit at preoperative and postoperative day 2 . The mean drop in hematocrit was found to be $3.46 \%$ in vaginal hysterectomy, $7 \%$ in abdominal hysterectomy and $7 \%$ in laparoscopic hysterectomy. The drop in hematocrit differed significantly among the surgical methods $(p<0.005)$. It was concluded that the surgical method with the lowest hematocrit drop was the vaginal hysterectomy method (3.46\%). Duration of hospitalization was found to differ among surgical methods; there were significant differences between the vaginal hysterectomy method and the abdominal hysterectomy and laparoscopic hysterectomy surgical methods $(p<0.05)$. The mean duration of hospitalization was 2 days in vaginal hysterectomy, 5 days in abdominal hysterectomy and 4 days in laparoscopic hysterectomy. No significant difference was observed between the abdominal hysterectomy and laparoscopic hysterectomy surgical methods with respect to duration of hospitalization $(\mathrm{p}>0.05)$. The surgical method that had the shortest hospitalization time was the vaginal hysterectomy method (two days). A statistically significant difference was found between duration of hospitalization and surgical types $(\mathrm{p}<0.005)$. Significant differences were observed between postop analgesic amount and the three different surgical types. It was concluded that the surgical type that necessitated the smallest amount of analgesics for the patients was the vaginal hysterectomy method (two days). The postop amount of analgesics differed significantly between the vaginal hysterectomy method and the abdominal hysterectomy and laparoscopic hysterectomy surgical methods $(\mathrm{p}<0.05)$. The mean postoperative analgesic need was 2 days in vaginal hysterectomy, 3 days in abdominal hysterectomy and 3 days in laparoscopic hysterectomy. A statistically significant difference was found between the three groups $(p<0.005)$. A difference was observed between hospital expenses and surgical methods. A significant difference was seen between

Table 2. Indications for Operation Types

\begin{tabular}{|l|c|c|c|c|}
\hline \multicolumn{1}{|c|}{ INDICATIONS } & $\begin{array}{c}\text { Vaginal } \\
\text { Hysterectomy }\end{array}$ & $\begin{array}{c}\text { Abdominal } \\
\text { Hysterectomy }\end{array}$ & $\begin{array}{c}\text { Laparoscopic } \\
\text { Hysterectomy }\end{array}$ & p \\
\hline CervicalIntraepithelial Neoplasia & $8.6 \%(\mathrm{n}=3)$ & $8.6 \%(\mathrm{n}=3)$ & $11.4 \%(\mathrm{n}=4)$ & \\
\cline { 1 - 4 } Endometrial Hyperplasia/Endometrial Polyp & $25.7 \%(\mathrm{n}=9)$ & $28.6 \%(\mathrm{n}=10)$ & $25.7 \%(\mathrm{n}=9)$ & \\
\cline { 1 - 4 } Adnexialmass & $2.9 \%(\mathrm{n}=1)$ & $2.9 \%(\mathrm{n}=1)$ & $2.9 \%(\mathrm{n}=1)$ & \multirow{2}{*}{0.999} \\
\cline { 1 - 4 } Myoma Uteri & $11.4 \%(\mathrm{n}=4)$ & $8.6 \%(\mathrm{n}=3)$ & $11.4 \%(\mathrm{n}=4)$ & \\
\cline { 1 - 3 } & $11.4 \%(\mathrm{n}=4)$ & $14.3 \%(\mathrm{n}=5)$ & $8.6 \%(\mathrm{n}=3)$ & \\
\hline Dysfunctional Uterine Bleeding & $17.1 \%(\mathrm{n}=6)$ & $14.3 \%(\mathrm{n}=5)$ & $20 \%(\mathrm{n}=7)$ \\
\hline Postmenopausal Bleeding & $22.9 \%(\mathrm{n}=8)$ & $22.9 \%(\mathrm{n}=8)$ & $20 \%(\mathrm{n}=7)$ & \\
\hline
\end{tabular}


the vaginal hysterectomy method and the laparoscopic hysterectomy surgical method $(\mathrm{p}<0.05)$. There was also a significant difference between the abdominal hysterectomy method and the laparoscopic hysterectomy surgical method $(p<0.05)$. No significant difference was seen between the abdominal hysterectomy and vaginal hysterectomy surgical methods with respect to hospital expenses $(p>0.05)$. The surgical method with the lowest hospital expenses was vaginal hysterectomy (1591.47 Turkish Liras (TL)) and this was found statistically significant $(\mathrm{p}<0.005)$. The mean cost was calculated to be TL1.591,47 for vaginal hysterectomy, TL1.855,70 for abdominal hysterectomy and TL $4.230,19$ for laparoscopic hysterectomy. As for wound site infection, there were no patients who had wound site infection among patients who underwent vaginal and laparoscopic hysterectomies and 3 patients among those who underwent abdominal hysterectomy. A statistically significant difference was found between the surgical types with respect to wound site infection $(\mathrm{p}<$ 0.005 ). In the abdominal hysterectomy method, wound site infection occurred in $8.6 \%$ of the patients, which was found to be significantly high $(\mathrm{p}<0.05)$. While there were no bladder or ureter complications in the patients who underwent vaginal hysterectomy, ureter complications were seen in 2 patients in abdominal hysterectomy and 3 patients in laparoscopic hysterectomy. There was no statistically significant difference between the three groups $(p>0.05)$. No intestinal complications were seen in the patients who underwent vaginal hysterectomy and abdominal hysterectomy, where as 1 patient had intestinal complication in the laparoscopic hysterectomy group. No significant difference was found between the hysterectomy types with respect to intestinal complications $(\mathrm{p}>0.005)$ (Table 3$)$. Generally speaking, there was no statistically significant difference between the surgical methods with re- spect to intestinal complications, bladder and ureter complications and blood transfusion $(\mathrm{p}>0.05)$. The number of patients who had blood transfusion was 1 in vaginal hysterectomy, 5 in abdominal hysterectomy and 2 in laparoscopic hysterectomy. No significant difference was found between the surgical types with respect to blood transfusion ( $\mathrm{p}>0.05)$.

\section{DISCUSSION}

Vaginal hysterectomy is a minimally invasive surgery involving few complications and morbidities and no scar tissue. Except for serious adhesive and large mass involving conditions such as severe endometriosis, pelvic inflammatory disease or adnexal pathology, vaginal hysterectomy is recommended in many studies as the method of first choice in patients for whom hysterectomy is decided due to benign indications $(8,9$, $11,12,13,20)$. In their two studies made in 1990 and 2002, Figueredo Netto O et al. have shown that prolapse is not the basic condition for vaginal hysterectomy and after applying anesthesia, uterus can be pulled down and vaginal hysterectomy can be performed with success $(12,21)$ Kumar et al. administered vaginal hysterectomy to 80 patients without prolapse and achieved a $95 \%$ success rate (22). These studies are supportive of our results. In their study with 250 patients, Doucette et al. administered vaginal hysterectomy to patients with common contraindications such as large uterus, nulliparity, past cesarean section and past laparotomy and argued that such contraindications should be considered rare contraindications (23). Kovac et al. also administered vaginal hysterectomy to patients other surgeons thought were not suitable for vaginal hysterectomy and achieved a $91 \%$ success rate (24). In a recent prospective study conducted by Ursuleanu et al., 816 patients, $56 \%$ of whom were nulliparous and $69 \%$

Table 3. Results of from blood transfusion to operation duration for Operation Types

\begin{tabular}{|l|c|c|c|c|}
\hline \multicolumn{1}{|c|}{ Factor } & $\begin{array}{c}\text { Vaginal } \\
\text { Hysterectomy }\end{array}$ & $\begin{array}{c}\text { Abdominal } \\
\text { Hysterectomy }\end{array}$ & $\begin{array}{c}\text { Laparoscopic } \\
\text { Hysterectomy }\end{array}$ & P value \\
\hline Duration of Operation & $37.54(27-55)$ & $46.43(36-70)$ & $156.63(125-200)$ & .000 \\
\hline Decrease in hematocrit & $3.46(0-8)$ & $7.00(3-13)$ & $7.00(3-11)$ & .000 \\
\hline Duration of hospitalization & $2(1-5)$ & $5(3-8)$ & $4(3-17)$ & .000 \\
\hline Hospital expenses (TL) & $\begin{array}{c}1.591,47 \\
(996,63-3.405,83)\end{array}$ & $\begin{array}{c}1.855,70 \\
(1.268,45-2.822,13)\end{array}$ & $\begin{array}{c}4.230,19 \\
(2.010,95-8.039,10)\end{array}$ & .000 \\
\hline Postop analgesia need & $2(1-4)$ & $3(2-6)$ & $3(2-14)$ & .000 \\
\hline $\begin{array}{l}\text { Complications of bladder } \\
\text { and ureter }\end{array}$ & $0 \%(\mathrm{n}=0)$ & $5.7 \%(\mathrm{n}=2)$ & $8.6 \%(\mathrm{n}=3)$ & .365 \\
\hline Wound site infection & $0 \%(\mathrm{n}=0)$ & $8.6 \%(\mathrm{n}=3)$ & $0 \%(\mathrm{n}=0)$ & .046 \\
\hline Intestinal complications & $0 \%(\mathrm{n}=0)$ & $0 \%(\mathrm{n}=0)$ & $2.9 \%(\mathrm{n}=1)$ & 1.00 \\
\hline Blood transfusion & $2.9 \%(\mathrm{n}=1)$ & $14.5 \%(\mathrm{n}=5)$ & $5.7 \%(\mathrm{n}=2)$ & 1.00 \\
\hline
\end{tabular}


with past cesarean section, underwent vaginal hysterectomy and no increase in complications was found at the end of the study (25). Compatible with the literature, vaginal hysterectomy was administered successfully also in our study to patients with past uterine surgery and to those who were nulliparous. These results show that past surgical operations including cesarean section do not constitute a contraindication for a vaginal approach in experienced hands. Some studies in the literature indicate that although vaginal hysterectomy has many superior aspects, the reason for its being used less in daily practice is the lack of training and experience. Tue et al. has conducted a retrospective study concerning this situation in America. They reviewed 94.599 patients who underwent hysterectomy between 2000 and 2005. Tue et al. found in their study that abdominal route was preferred at a rate of $82 \%$ in hospitals providing training and showed that vaginal hysterectomy was taught less to the new generation of gynecologic surgeons (26). Varma et al. adopted a positive approach to vaginal hysterectomy in their study and raised the rate of vaginal hysterectomy from $32 \%$ to $95 \%$ without increasing morbidity at the end of their 5-year study (27) We compared in our study the patients without prolapses who underwent vaginal hysterectomy and abdominal and laparoscopic hysterectomies in terms of duration of operation, decrease in hematocrit, cost, duration of hospitalization, postoperative amount of analgesia, need for blood transfusion, wound site infection, and complications of intestines, bladder and ureters and found vaginal hysterectomy advantageous in many respects. The studies in the literature have also shown that, with an operation time ranging between 30 and $140 \mathrm{~min}$., vaginal hysterectomy has a shorter operation time than those of abdominal and laparoscopic hysterectomies (28). Cochrane compared the duration of operation in vaginal, laparoscopic and abdominal hysterectomies in the meta-analysis they made in 2015 with the inclusion of 5102 patients. They showed that laparoscopic hysterectomy, a minimally invasive surgery like vaginal hysterectomy, had the longest operation time (29) Similar to these results, we also found in our study that, with a mean operation time of 37.54 min., the patients to whom we administered vaginal hysterectomy had a shorter operation time than those of abdominal and laparoscopic hysterectomies. Even though some studies have reported that vaginal hysterectomy causes more blood loss (17), many other studies in the literature defend that vaginal hysterectomy is an operation causing the least amount of bleeding (16). We also showed in our study that the amount of bleeding was the least. A majority of the studies in the literature have found that the operation with the highest cost is laparoscopic hysterectomy due to the prices of the materials used during the operation. No significant difference has been found between abdominal and vaginal hysterectomies with respect to cost (23). However, with a mean cost of TL 1.591.47, vaginal hysterectomy was found to be a more cost effective technique than abdominal and laparoscopic hysterectomies in our study. A large portion of the studies in the literature have found that vaginal and laparoscopic hysterectomies, which are minimally invasive surgeries, are superior to abdominal hysterectomy with respect to duration of hospitalization. The mean duration of hospitalization was calculated to be 2 days for vaginal hysterectomy in our study. Compatible with the literature, vaginal hysterectomy was shown to be superior to abdominal and laparoscopic hysterectomies in terms of duration of hospitalization. In most of the studies in the literature, the postoperative need for analgesics has been shown to be twice as much in abdominal hysterectomy as in vaginal and laparoscopic hysterectomies (23). This is due to the abdominal incision and the procedure itself. As the tissue trauma increases, the need for analgesia also increases. Similar to the literature, the need for analgesics in our study was calculated to be 2 days on the average for vaginal hysterectomy, showing its superiority to laparoscopic and abdominal hysterectomies. In almost all of the studies in the literature, the technique that was found to have the highest risk of wound site infection was abdominal hysterectomy due to the abdominal incision involved in it (23). Similarly, laparoscopic hysterectomy has been also shown to involve a higher risk of infection than vaginal hysterectomy, however small the difference may be (23). Unlike the literature, we did not find any significant difference between laparoscopic and vaginal hysterectomies with respect to wound site infection in our study, but found vaginal hysterectomy superior to abdominal hysterectomy as in the literature. A large portion of the studies in the literature have shown that laparoscopic hysterectomy is twice as risky as abdominal and vaginal hysterectomies with respect to complications of bladder and ureter (23); moreover, the intestinal perforation rate is thought to increase during laparoscopic port entries (13). Shown as the most invasive technique in the literature, abdominal hysterectomy has the highest probability of requiring blood transfusion (23). Unlike the data in the literature, we did not find in our study any significant difference between abdominal, laparoscopic and vaginal hysterectomies in terms of blood transfusion or complications of the bladder, ureters and intestines. Vaginal hysterectomy was found superior to laparoscopic and abdominal hysterectomies with respect to duration of operation, decrease in hematocrit, duration of hospitalization, and postoperative need for analgesics. Older patients and those with higher anesthe- 
tic ASA scores due to their medical diseases usually tolerate vaginal hysterectomy better than abdominal and laparoscopic hysterectomies (23). Operations of highly obese patients make vaginal, abdominal and laparoscopic hysterectomies technically difficult, but such difficulty is less in vaginal hysterectomy (23). Additional conditions associated with vaginal wall relaxation such as cystocele and rectocele can be repaired more easily through the vaginal route (23). Vaginal hysterectomy requires a shorter operation time than abdominal and laparoscopic hysterectomies (15). Vaginal hysterectomy has been evidenced to have a lower cost than laparoscopic hysterectomy, but there are no studies comparing its cost to that of abdominal hysterectomy. The probability of ureter injury is the least in vaginal hysterectomy and the most in laparoscopic hysterectomy (13). Similar to our study, vaginal hysterectomy has been found to be safer, its postop pain to be less, duration of hospitalization to be shorter, patient satisfaction to be higher and its cost to be less as compared to the other methods in both the broad-scale Cochrane meta-analysis and the eVALute study (10). The major limitation of our study was that it was planned as a retrospective study, but it may serve as a guide for larger randomized controlled studies that may be conducted to clearly show the superiority of vaginal hysterectomy in patients without uterine prolapse.

\section{CONCLUSION}

For many years, vaginal hysterectomy has been delimited with the indication of uterine prolapse. Many studies in the literature support the fact that the vaginal hysterectomy method can be preferred to other meth- ods in also benign indications without prolapse. When compared to laparoscopic and abdominal hysterectomies, vaginal hysterectomy is more advantageous in duration of operation, amount of bleeding, cost, duration of hospitalization, wound site infection, intraabdominal adhesion and postop analgesia need. Adequate training should be provided about the practice of vaginal hysterectomy particularly in uteruses without prolapses during the specialization courses in training hospitals and hysterectomy through vaginal route should be promoted.

\section{Abbreviations:}

OMU - OndokuzMayıs University

ACOG - American College of Obstetrics and Gynecology

USA - United States of America

ASA - American Society of Anesthesiologists

IM - Intramuscular

IV - Intraveous

SPSS - Statistics Program for Social Sciences

ANOVA - One Way Analysis of Variance

BMI — body mass index

DUB - dysfunctional uterine bleeding

TL - Turkish Liras

\section{DECLARATION OF INTEREST}

The authors declare that there are no conflicts of interest.

\section{Licensing}

This work is licensed under a Creative Commons Attribution 4.0 International (CC BY 4.0) License.

\title{
Sažetak
}

\section{VAGINALNA HISTEREKTOMIJA U POREĐENJU SA ABDOMINALNOM I LAPAROSKOPSKOM HISTEREKTOMIJOM KOD PACIJENTKINJA BEZ PROLAPSA UTERUSA}

\author{
Birsen Bilge, ${ }^{1}$ Ayse Zehra Ozdemir, ${ }^{1}$ Pervin Karli, ${ }^{2}$ Idris Kocak ${ }^{1}$ \\ ${ }^{1}$ Ondokuz Mayis University, Department of Gynecology and Obstetrics, Turkey \\ ${ }_{2}$ Amasya University, Department of Gynecology and Obstetrics, Turkey
}

Uvod: Osim indikacije za prolaps materice, vaginalna histerektomija je bila manje popularna od abdominalne histerektomije zato što je abdominalna histerektomija smatrana za bezbedniju i lakšu, a hirurzima često manjka dovoljno iskustva za vaginalnu histerektomiju. Ova studija ima za cilj da uporedi grupu pacijentkinja bez prolapsa uterusa, koje su imale vaginalnu histerektomiju sa drugom grupom pacijentkinja koje su imale abdominalnu i laparaskopsku histerektomiju u odnosu na intraoperativne i rane postoperativne komplikacije.

Materijal i metode: Retrospektivno smo pregledali kartone pacijentkinja sa ginekološke klinike Univerziteta Ondokuz Mayis, u Turskoj, između januara 2013 i februara 2018, kod kojih je urađena histerektomija zbog benignih indikacija, izuzev prolapsa materice. U studiju je uključeno ukupno 105 pacijentkinja, 35 iz svake od grupa koje su imale abdominalnu, lapara- 
skopsku i vaginalnu histerektomiju. Grupa sa vaginalnom histerektomijom je upoređivana sa grupom sa abdominalnom i laparaskopskom histerektomijom u smislu trajanja operacije, smanjenja hematokrita, transfuzije krvi, trajanja hospitalizacije, bolničkih troškova, postoperativnog bola, infekcija rane, kao i komplikacija creva, bešike i uretera.

Rezultati: Nisu pronađene statistički značajne razlike između demografskih karakteristika grupa. Pokazano je da je vaginalna histerektomija superiornija u odnosu na laparaskopsku i abdominalnu histerektomiju u smislu trajanja operacije $(\mathrm{p}<0.005)$, smanjenje hematokrita pokazuje količinu krvarenja ( $\mathrm{p}<0.005)$, trajanja hospitalizacije $(\mathrm{p}<0.005)$, bolničkih troškova

\section{REFERENCES}

1. De Frances CJ, Lucas CA, Buie VC, Golosinskiy A. 2006 National Hospital Discharge Survey. Natl Health Stat Report. 2008; 5: 1-20.

2. Whiteman MK. Hillis SD, Jamieson DJ, Morrow B, Podgornik MN, Brett KM et al. Inpatient hysterectomy surveillance in the United States, 2000-2004. Am J Obstet Gynecol. 2008; 198(1): 34 e1-7.

3. Lepine LA Hillis SD, Marcbanks PA, Koonin LM, Morrow B, Kieke BA et al. Hysterectomy surveillance-United States 1980-1993. MMWR CDC Surveill Summ. 1997; 46(4): 1-15.

4. Vessey MP. Villard Mackintosh L, McPherson K, Coulter A. Yeates D. The epidemiology of hysterectomy: findings in a large cohort study. Br J Obstet Gynaecol. 1992; 99(5): 402-7.

5. Van Keep PA. Wildemeersch D. Lehert P. Hysterectomy in six European countries. Maturitas. 1983; 5(2): 69-75.

6. Hirsc, NA. Technologies for the Treatment of Menorrhagia and Uterine Myomas, Australian Institute of Health Welfare: HealthCare Technology Series No. 10, AGPS, Canberra, 1993.

7. Luoto R, Kaprio J. Keskimaki I. Pohjanlahti JP. Rutanen EM. ancidence, causes and surgical methods for hysterectomy in Finland 1987-1989. Int J Epidemiol. 1994; 23(2): 348-58.

8. Gollop TR, Santos AG, Rossi AG, Bianchi RF. Vaginal hysterectomy in non-prolapsed uteri: a 6 year experience. Einstein (SnoPaulo). 2012; 10(4): 462-5.

9. ACOG Committee Opinion No. 444: choosing the route of hysterectomy for benign disease. Obstet Gynecol. 2009; 114(5): 1156-8.

10. Nieboer TE, Johnson N, Lethaby A, Tavender E, Curr E, Garry R et al. Surgical approach to hysterectomy for benign gynaecological disease. Cochrane Database Syst Rev 2009; (3): CD003677.

11. Balakrishnan D, Dibyajyoti GA. Comparison between non-descent vaginal hysterectomy and total abdominal hysterectomy. J Cl2n D2ag Res. 2016; 10(1): QC11-4. $(\mathrm{p}<0.005)$, i količine potrebnih postoperativnih analgetika $(p<0.005)$. Infekcija rane je češća kod abdominalne histerektomije nego kod vaginalne i laparoskopske $(\mathrm{p}<0.005)$. Nije pronađena statistički značajna razlika između vaginalnih, abdominalnih i laparaskopskih histerektomija u odnosu na transfuziju krvi i komplikacije creva, bešike i uretera $(\mathrm{p}>0.005)$.

Zaključak: Najvažniji faktor u odabiru metode histerektomije jeste iskustvo hirurga. Međutim vaginalna histerektomija bi trebala biti primarno poželjna metoda, ako je moguće, jer je u mnogim pogledima povoljnija.

Ključne reči: Histerektomija, minimalno invazivna hirurgija, vaginalna histerektomija.

12. Wolman I. Berek and Novak's Gynecology 15th Edition: Lippincott Williams and Wilkins, 2012, 1560 pp, Hardcover, Rs. 2659 on www. flipkart. com.

13. Salcedo FL. Vaginal hysterectomy in non-prolapsed uteruses: "no scar hysterectomy". Int Urogynecol J Pelvic Floor Dysfunct. 2009; 20(9): 1009-12.

14. Committee on Gynecologic Practice..Committee Opinion No 701: Choosing the route of hysterectomy for benign disease. Obstet Gynecol. 2017; 129(6): e155-9.

15. Schindlbeck C, Klauser K, Dian D, Janni W, Friese K.. Comparison of total laparoscopic, vaginal hysterectomy. Arch Gynecol Obstet. 2008; 277(4): 331-7.

16. Wattiez A, Soriano D, Cohen SB, Nervo P, Canis M, Botchorishvili $\mathrm{R}$ et al. The learning curve of total laparoscopic hysterectomy: comparative analysis of 1647 cases. J Am Assoc Gynecol Laparosc. 2002; 9(3): 339-45.

17. Richardson RE, Bournas N, Magos AL. Is laparoscopichysterectomy a waste of time? Lancet. 1995; 345(8941): 36-41.

18. Garry R. The future of hysterectomy. BJOG. 2005; 112(2): 133-9.

19. Dolanbay M, Kutuk MS, Ozgun MT, Uludag S, Sahin Y. Laparoscopically assisted vaginal hysterectomy for enlarged uterus: operative outcomes and the learningcurve. Ginekol Pol. 2016; 87(5): 333-7.

20. Jones HW, Rock JA. Te Linde's operative gynecology. Lippincott Williams \& Wilkins, 2015.

21. Sushil K, Antony ZK. Vaginal hysterectomy for benign nonprolapsed uterus. Initial Experience. J Obstet Gynaecol Ind. 2004; 54(1): 60-3.

22. Doucette RC, Sharp HT, Alder SC. Challenging generally accepted contraindications to vaginal hysterectomy. Am J ObstetGynecol. 2001; 184(7): 1386-89.

23. Kovac SR, Cruikshank SH, Retto HF. Laparoscopy assisted vaginal hysterectomy. J GynecolSurg. 1990; 6(3): 185-93.

14. Ursuleanu A, Nicodin O, Gussi I, Niculescu N, Costachescu G. Results of extension of classic indications of vaginal hysterectomy for benign uterine conditions. Chirurgia (Bucur). 2012; 107(6): 761-6.

25. Tu FF, Beaumont JL, Senapati S, Gordon TE. Route of hysterectomy influence and teaching hospital status. Obstet Gynecol. 2009; 114(1): 73-8. 
26. Varma R, Tahseen S, Lokugamage AU, Kunde D. Vaginal route as the norm when planning hysterectomy for benign conditions: change in practice. Obstet Gynecol. 2001; 97(4): 613-6.

27. Paparella R, Sizzi O, Rossetti A, De Benedittis F, Paparella R. Vaginal hysterectomy in generally considered contraindications to vaginal surgery. Arch Gynecol Obstet. 2004; 270(2): 104-9.
28. Aarts JW, Nieboer TE, Johnson N, Tavender E, Garry R, Mol BW, et al. Surgical approach to hysterectomy for benign gynaecological disease. Cochrane Database of Syst Rev. 2015; (8): CD003677.

29. Doganay M, Yildiz Y, Tonguc E, Var T, Karayalcin R, Eryılmaz OG, et al. Abdominal, vaginal and total laparoscopic hysterectomy: perioperative morbidity. Arch Gynecol Obstet. 2011; 284(2): 385-9.

\section{Correspondence to/Autor za korespondenciju}

Karli Pervin

Amasya University, Department of Gynecology and Obstetrics, Turkey

email: parpi2300@hotmail.com 